\title{
Control of waste water treatment combined with irrigation
}

\author{
Erik Dahlquist $^{1}$ Eva Nordlander ${ }^{1}$ Eva Eva Thorin ${ }^{1} \quad$ Anders Wallin $^{1,2}$ Anders Avelin ${ }^{1,2}$ \\ ${ }^{1}$ School of Business, Society and Engineering, Future Energy Center, Mälardalen University, Västerås, Sweden \\ ${ }^{2}$ ABB Process Industries AB, Västerås, Sweden
}

\begin{abstract}
In waste water treatment using biological treatment processes normally phosphorous, nitrous compounds as well as organic matter are removed. It is also important to remove or kill pathogens that otherwise could cause diseases. The surplus of bio-sludge is used to produce biogas. In the paper four different alternatives for system design and operations of systems was discussed. The alternatives integrate the waste water treatment and irrigation of farmland using the water taken out from different positions in the waste water treatment plant.
\end{abstract}

Keywords: waste water treatment, farming, irrigation, control.

\section{Introduction}

Irrigation is becoming more important globally as water has become a scarce resource. By using waste water (WW) the nutrients in the wastewater (phosphorous and nitrogen-compounds) can be used as fertilizers. At the same time it is necessary to manage pathogens as well as toxic substance to avoid spreading diseases and harmful substances through the crops. The water can be taken out at different positions in the Waste water treatment plant (WWTP). Depending on the demand of water respectively nutrients different outtakes can be feasible during different situations over the yea.

In Figure 1, several different layouts have been made for different options for waste water treatment. The first step is pre-sedimentation treatment where solid material is settled. A precipitating agent, such as $\mathrm{FeCl}_{3}$, could added to be able to separate smaller particles.

Addition of a precipation agent may lead to a deficiency of carbon for the later activated sludge process. Extra carbon source can be from either reject water or addition of e.g. methanol or glycol. This will enhance the denitrification in the activated sludge (AS) step. Most of the $\mathrm{PO}_{4}$ will be removed in the form of $\mathrm{FePO}_{4}$. This will be digested in the anaerobic digester, but still most of the phosphorous $(\mathrm{P})$ will be removed as $\mathrm{FePO}_{4}$ in the residues after the digestion.

If no metal salt is added, only large particles will be removed, there is still several alternatives for the following process steps. There could be either an anoxic or anaerobic steps followed by aeration. This will be good both for biological removal of $\mathrm{P}$ and $\mathrm{N}$ compounds as well as denitrification in the aerobic step. To build as much $\mathrm{PO}_{4}$ as possible into biomaterial, microalgae could be included, as algae are good at incorporating the $\mathrm{PO}_{4}$ (Anbalagan et al., 2017). The microalgae also produce $\mathrm{O}_{2}$, which would reduce the demand for aeration. The drawback is that microalgae need sunlight or artificial lighting and the reaction rate might also be lower. Microalgae was not included in this, although it might be interesting in the future.

The sludge is normally separated after the biological processes and part of it recirculated, while the rest is anaerobically digested to produce biogas (which consist mostly of methane). The sludge can either be concentration before or after the digestion. The resulting liquid, can either be recirculated to before the biological processes, or first be treated with e.g. nano- or reverse osmosis filtration. Filtration can be organic acids (NF) or even ammoniac (RO). The permeate water will be quite lean and not add burden to the biological processes. Levlin and Hultman (2010) have described how $\mathrm{PO}_{4}$ could be recovered by precipitating it with $\mathrm{CaO}$ to form $\mathrm{CaPO}_{4}$. This could be an alternative for storing $\mathrm{PO}_{4}$ in a compact way. Toomiste et al (2010) have followed TP (total P) respectively DP (Dissolved P) through the different processes in the WWTP. Of the TP in the reject water from the digester $90 \%$ is dissolved, and thus in the liquid phase. Morse et al (1998) shows that anaerobic conditions can release the biologically bound $\mathrm{PO}_{4}$.

Concerning nitrogen balance Kanders (2019) has studied both normal activated sludge processes and those with anammox-bacteria. It is assumed that approximately $40 \%$ of the incoming $\mathrm{NH}_{4}$ is built in to the sludge microorganisms, while $40 \%$ is removed to air as $\mathrm{N}_{2}$. If anammox is used half of the electricity demand of the aeration could be, however a solid matrix where the bacteria can grow and form a film is needed. Kanders (2019) has primarily investigated how the anammox can be utilized for the reject water where the concentrations of ammonium is high and the volume flow much lower (only approximately $1 \%$ of the inflow). To combine WWT with irrigation water and sludge can be taken out from different positions in the WWT process. Most heavy metals should be in the solute. It would be interesting to wash the filter cake to wash out the metal ions. These then can be removed by absorption in e.g. an ion-exchanger. 
In the denitrification, also $\mathrm{N} 2 \mathrm{O}$ may be formed. $\mathrm{By}$ controlling the $\mathrm{pH}$ to above 7.6 almost no $\mathrm{N}_{2} \mathrm{O}$ was formed while a lot was formed at $\mathrm{pH} 6$ according to
Desloover et al (2012) and Kanders (2019). The solid residues after the fermentation also should be recirculated to the farmland.

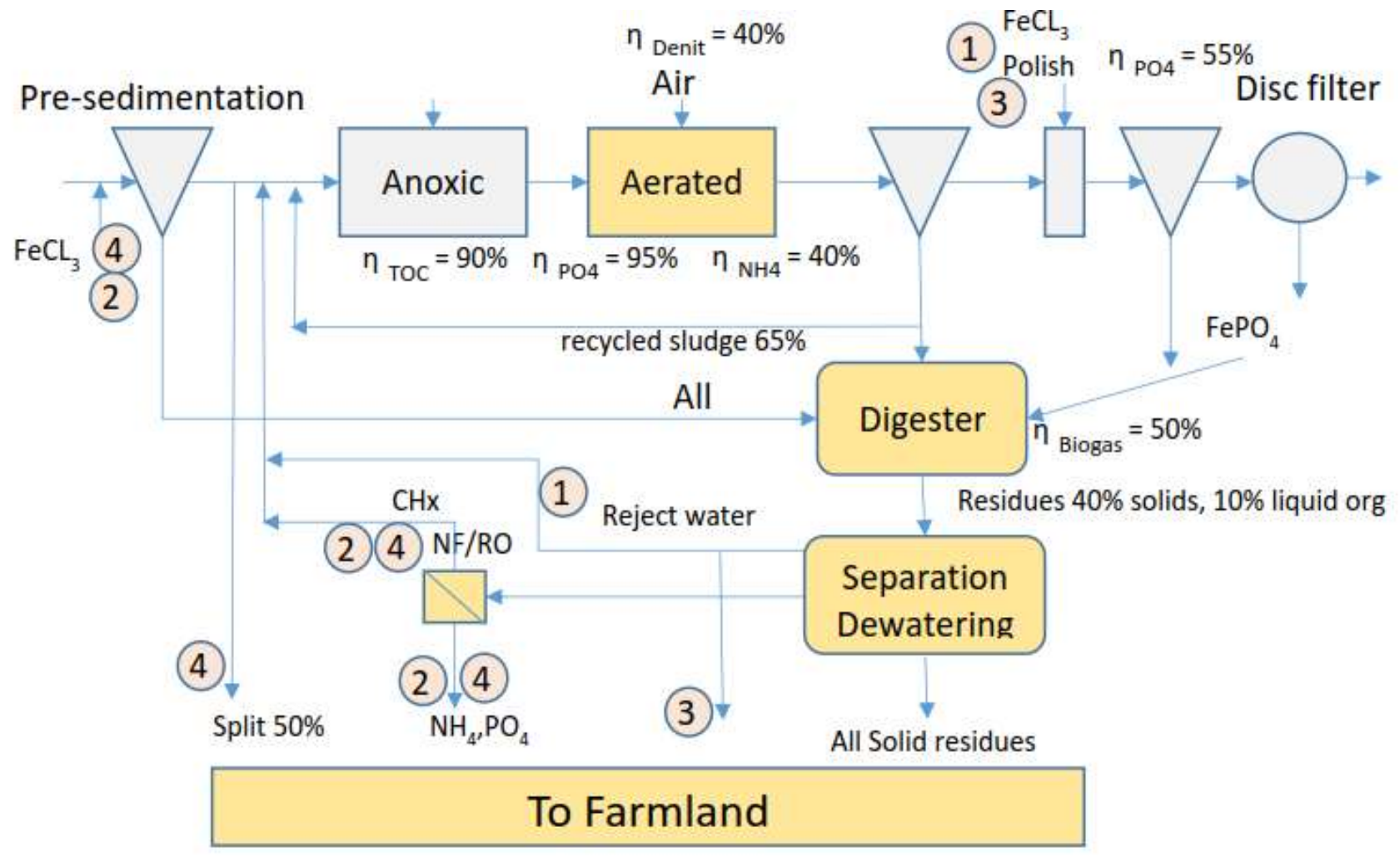

Figure 1. A general layout of four different cases for a WWTP.

\section{Modelling}

From a modeling perspective primarily material and energy blanaces has developed. They are in reality semi steady state as steady state balances are calculated for a given inflow of water and TOC (Total Organic Carbon), TP and TN (Total Nitrogen). For different situations a new balance is calculated. In this paper four different cases have been studied.

This includes continuity equations for massflow (m) times concentration (x) for each stream in (n) and stream out (k):

$$
\sum_{i}^{n} m_{i, \text { in }} x_{i, \text { in }}=\sum_{i}^{k} m_{i, \text { out }} x_{i, \text { out }}
$$

The energy used in activated sludge processes are mainly electricity for aeration. In (Mizuta and Shimada, 2010) a benchmark has been made for different wastewater treatment plants (WWTP) and found that in Japan $0.30-1.89 \mathrm{kWh} / \mathrm{m} 3$ was used for aeration. The main difference was depending on the size of the plant, and thereby the efficiency. Soares et al. (2017) present the figure $0.3-0.6 \mathrm{kWh} / \mathrm{m} 3$ in conventional activated sludge processes, which is in the lower range of what Mizuta and Shimada presented, for WWTPs in Brazil.
Enerwater (2015) reports that $1 \%$ of electric power in Germany is for WWT in some 10000 WWTPs. The study included 369 WWTPs in EU, representing the treatment of about $15,742,816 \mathrm{PE}$ and a total energy consumption of $1,736,735 \mathrm{kWh} /$ day, was performed. Assumption was $120 \mathrm{gCOD} /(\mathrm{PE} * \mathrm{~d})$ in $\mathrm{EU}$ and 160 $\mathrm{gCOD} / \mathrm{PE}$ in the US. A specific energy use of 0.13 $\mathrm{kWh} / \mathrm{m} 3$ was found for larger plants, while for smaller plants values up to $5.5 \mathrm{kWh} / \mathrm{m} 3$ could be seen. 2000 $\mathrm{kWh} /\left(\mathrm{PE}^{*} \mathrm{y}\right)$ could be for smaller plants, while larger plants have in the range 20 to $60 \mathrm{kWh} /\left(\mathrm{PE}^{*} \mathrm{y}\right)$. This can be summarized in some key values for big WWTPs: $0.28-0.61 \mathrm{kWh} / \mathrm{m} 3,27.4-47.9 \mathrm{kWh} / \mathrm{PE} * \mathrm{y}$ and $0.55-1.10$ $\mathrm{kWh} / \mathrm{kgCODrem}$.

A value of value $0.55 \mathrm{kWh} / \mathrm{kg}$ COD was used, which means approximately $1,8 \mathrm{kWh} / \mathrm{kg}$ TOC if the following conversion formula is used

$$
\mathrm{COD}=49.2+3 * \mathrm{TOC}
$$

from Dubber and Gray (2010). They have developed this from a number of different influent water. The electric demand is then

$$
\mathrm{kWel}=\mathrm{kg} \text { biomass TOC } / \mathrm{s} * 1.8 \mathrm{kWh} / \mathrm{kg} \text { TOC. }
$$

For biogas production it was assumed that the biomass to have the formula $\mathrm{C}_{5} \mathrm{H}_{7} \mathrm{O}_{2} \mathrm{~N}+\mathrm{PO}_{4}$ and the 
energy content in the biomass is $21.2 \mathrm{MJ} / \mathrm{kg}$. Sludge is taken to a digester where anaerobic fermentation convert approximately $50 \%\left(\eta_{\text {biogas }}=0.5\right)$ of the organic material to biogas, which was assumed to consist of $65 \% \mathrm{CH}_{4}$ and $35 \% \mathrm{CO}_{2}$.

$$
\mathrm{kWCH}_{4}=\mathrm{kg} \text { biomass TOC to digester/s* } \eta_{\text {biogas }} * 0.65 \text {. }
$$

The water flow has just been given for the in-flow, as the concentrations can vary a lot. As there will always be cleaned effluent water that can be used, this is not a limiting resource and thus is neglected in the mass balances.

The mass balance has been evaluated for the four different cases based on assumption of $3600 \mathrm{~m}^{3} / \mathrm{h}(3600$ ton $/ \mathrm{h}$ ) inflow water and the following values have been used for separation or reactivity efficiencies: $\eta_{\text {pre,TOC, }}$ $\eta_{\mathrm{Pre}, \mathrm{PO} 4}$ and $\eta_{\text {pre, } \mathrm{NH} 4}=20 \%$ case 1,3 and 4 , while $35 \%$ for case 2 with $\eta_{\text {pre,PO4 }}>95 \% ; \eta_{\mathrm{AS}, \mathrm{TOC}}=90 \% ; \eta_{\mathrm{AS}, \mathrm{PO} 4}=95 \%$, $\eta_{\mathrm{AS}, \mathrm{NH} 4 \text {,sep }}=40 \%, \quad \eta_{\mathrm{AS}, \mathrm{NH} 4 \text {,denit }}=40 \%$, sludge recirculation $65 \%$. In Figure 1, we also see the flows that differentiate the four cases.

\section{Studied cases}

Four different cases were studied, with wastewater from different positions in the WWTP. An inflow of 1 $\mathrm{m} 3 / \mathrm{s}$ was used (corresponding to $500000 \mathrm{PE}$ ) with 224 $\mathrm{mgTOC} / 1$ or $720 \mathrm{mgCOD} / 1$ in the inflow. The four cases are described below:

Case 1: This is the reference case without addition of $\mathrm{FeCl}_{3}$ to the pre-treatment step, but with polishing with $\mathrm{FeCl}_{3}$ after the activated sludge. All reject water is recycled back before the AS.

Case 2: $\mathrm{In}$ this case, $\mathrm{FeCl}_{3}$ is added before the presedimentation to precipitate most of the $\mathrm{PO}_{4}$ and significant amount of TOC and $\mathrm{NH}_{4}$ as well. This is sent to fermentation. Reject water from the separation after the digester is filtered in a nano membrane filter and organics is recycled to the AS while permeate with $\mathrm{PO}_{4}$, $\mathrm{K}$ and $\mathrm{NH}_{4}$ is sent to the farmland. Totally treated water is used for irrigation as much as needed with low risk for polluting crops, but also we do not add any burden from reject water with respect to $\mathrm{NH}_{4}$ and $\mathrm{PO}_{4}$ to the AS in the WWTP.

Case 3: No pre-precipitation with $\mathrm{FeCl}_{3}$ before presedimenation, but addition after the AS for polishing. Use of reject water from the fermentation directly to the farmland. Here it should also be possible to remove heavy metals if needed from the liquid phase before distribution to the farmland.

Case 4: Take out a significant part of influent water $(50 \%)$ after the pre-sedimentation, after addition of $\mathrm{FeCl}_{3}$. Infectious microorganisms might be a problem if spread to growing plants if infectious species survive. Though low temperature or sun light at the field should kill most. Reject water is filtered in a membrane filter. Hydrocarbons are recycled from reject water (reject), while the permeate with $\mathrm{NH}_{4}, \mathrm{PO}_{4}$ and $\mathrm{K}$ is distributed to the farmland.

For cases 1 and 3, a pre-separation of coarse material without any chemical addition was assumed, but with addition of $\mathrm{FeCl}_{3}$ in case 2 and 4. Pre-separation was followed by an activated sludge (AS) process with anoxic and aerated vessels and after that sedimentation. $65 \%$ of the sludge is recirculated while $35 \%$ goes to biogas production in an anaerobic digestion process. The sludge after the digestion goes to farmland after dewatering. The reject water after separation (press or centrifuge) goes back to the AS process in case 1, but is separated in a NF (+ RO) -filter in cases 2 and 3. The filtrate from the NF filter goes to farmland. If there is a RO filter after the NF, the reject from the NF goes to the AS as a carbon source in case 2 (where there otherwise will be a deficiency of organics), while the permeate goes back to the process or is used as irrigation water (this will be pathogen free, and can be used also for vegetables). In case 3 the reject water goes back directly to the farmland without any NF/RO. The efficiency $\eta$ in the different process steps are seen also in Figure 1. The following values has been used for the efficiencies: $\eta_{\text {pre,TOC }}, \eta_{\text {Pre,PO4 }}$ and $\eta_{\text {pre,NH4 }}=20 \%$ for cases 1,3 and 4 , while $35 \%$ for case 2 with $\eta_{\text {pre,PO4 }}>95 \%$; $\eta_{\text {AS,TOC }}=90 \%$; $\eta_{\mathrm{AS}, \mathrm{PO} 4}=95 \%, \eta_{\mathrm{AS}, \mathrm{NH} 4, \mathrm{sep}}=40 \%, \eta_{\mathrm{AS}, \mathrm{NH} 4 \text {,denit }}=40 \%$, sludge recirculation $65 \%$. Figure 1 illustrates the different flows for the four cases.

There is also one other issue to consider. Aside of $\mathrm{N}_{2}$ also $\mathrm{N}_{2} \mathrm{O}$ may be formed in the biological process? By controlling the $\mathrm{pH}$ to above 7.6 almost no $\mathrm{N}_{2} \mathrm{O}$ was formed while a lot was formed at $\mathrm{pH}=6$ (Desloover et al., 2012; Kanders, 2019).

\section{Results and discussion}

The mass balance for the four cases 1-4 can be seen in Table 1. In Figure 2, data from Table 1 are presented for the four cases with one variable at a time, sorting from highest to lowest value. The hydrocarbons sent to the farmland will be much higher $(516 \mathrm{kgTOC} / \mathrm{h})$ for case 4 than the other three cases (310-336 kgTOC/h), but less methane will be produced.

From Figure 2, it can can seen that there is more TOC in the organic effluent from case 4 but much more $\mathrm{P}$ in cases 1 and 3, and more $\mathrm{N}-\mathrm{NH}_{4}$ in case 1 . Case 2 and 4 will have significantly lower emissions of $\mathrm{PO}_{4}$ while case 2 is best for $\mathrm{N}$-removal and case 4 best with respect to TOC in the effluent. On the other hand, the phosphate will be more biologically active in the soil at the farmland in cases 1 and 3, as most is taken up in the biomass, and then released in the anaerobic fermentation. The $\mathrm{FePO}_{4}$ can be too stabile for efficient use in farming as a fertilizer, while the Phosphor bound in the cells is much easier to release. 
Table 1. Material balance for the four operational/configurational cases from simulation.

\begin{tabular}{|c|c|c|c|c|c|c|c|c|c|c|c|c|c|}
\hline & \multicolumn{2}{|c|}{ total flow $\mathrm{C} 5 \mathrm{H} 7 \mathrm{O} 2 \mathrm{~N}$} & & & & \multirow{2}{*}{$\begin{array}{l}\mathrm{PO4} \\
\mathrm{kgTP} / \mathrm{h}\end{array}$} & & & & $\mathrm{N}$-comp & & & \multirow[b]{3}{*}{ case 4} \\
\hline & \multirow[t]{2}{*}{$\mathrm{kg} / \mathrm{h}$} & \multirow{2}{*}{$\begin{array}{l}\mathrm{kg} \text { TOC/h } \\
\text { case } 1\end{array}$} & \multicolumn{2}{|c|}{$\mathrm{FeCl} 3$ at pre-sep } & & & & & & $\mathrm{kg} \mathrm{NH} 4 / \mathrm{h}$ & & & \\
\hline & & & case 2 & case 3 & case 4 & $\operatorname{cas} 1$ & case 2 & case 3 & case 4 & case $1 \mathrm{c}$ & case 2 & case 3 & \\
\hline Feed water & 3600000 & 806 & 806 & 806 & 806 & 12 & 12 & 12 & 12 & 147 & 147 & 147 & 147 \\
\hline pre-sep & $n_{\text {ore }}=$ & 0,20 & 0,35 & 0,20 & 0,35 & 0,20 & 0,90 & 0,20 & 0,90 & 0,20 & 0,35 & 0,20 & 0,35 \\
\hline \multicolumn{2}{|c|}{ separated (sludge) } & 161 & $282^{\prime}$ & 161 & $282^{\prime}$ & 2,3 & 10,4 & 2,3 & $10,4^{\prime}$ & 29 & 52 & 29 & 52 \\
\hline left to AS & & 645 & 524. & 645 & 524 & 9,22 & 1,15 & 9,22 & 1,15 & 118 & 96 & 118 & 96 \\
\hline \multicolumn{2}{|l|}{ AS total load } & 1023 & $831^{\prime \prime}$ & 1023 & 831 & 14,91 & 1,86 & 14,91 & $1,86^{\prime}$ & 148 & 121 & 148 & 121 \\
\hline \multicolumn{2}{|l|}{ Split before AS } & & & & 0,50 & & & & 0,5 & & & & 0,5 \\
\hline \multicolumn{2}{|l|}{ to Farmland } & & & & 262 & & & & 0,576 & & & & 48 \\
\hline \multicolumn{3}{|c|}{ left to AS incl sludge recycle } & & & 432 & & & & 0,9504 & & & & 79 \\
\hline \multicolumn{2}{|c|}{ sludge sep eff $\eta_{\text {AS }}=$} & 0,900 & 0,900 & 0,900 & 0,900 & 0,95 & 0,95 & 0,95 & 0,95 & 0,4 & 0,4 & 0,4 & 0,4 \\
\hline \multicolumn{2}{|c|}{ denitrific eff $\eta_{\text {AS,DENIT }}=$} & & & & & & & & & 0,4 & 0,4 & 0,4 & 0,4 \\
\hline \multicolumn{2}{|c|}{ left after AS (water) } & 102 & 83 & $102^{\prime}$ & 43 & 0,75 & 0,09 & 0,75 & 0,05 & 30 & 24 & 30 & 16 \\
\hline \multicolumn{2}{|c|}{ sludge $(\mathrm{CH}, \mathrm{P}, \mathrm{NH} 4)$} & 920 & 748 & $920^{\prime}$ & 389 & 14,16 & 1,77 & $14,16^{\prime}$ & 0,90 & 59 & 48 & 59 & 32 \\
\hline \multicolumn{2}{|c|}{$\mathrm{NH} 4$ removed as N2 } & & & & & & & & & 59 & 48 & 59 & 32 \\
\hline \multicolumn{2}{|c|}{ NH4 into sludge } & & & & & & & & & 59 & 48 & 59 & 32 \\
\hline \multicolumn{2}{|l|}{ Sludge recycle \% } & 0,650 & 0,650 & 0,650 & 0,650 & 0,65 & 0,65 & 0,65 & 0,65 & 0,65 & 0,65 & 0,65 & 0,65 \\
\hline Sludge recycle & & 598 & 486 & 598 & 253 & 9,20 & 1,15 & 9,20 & 0,59 & 39 & 31 & 39 & 21 \\
\hline \multicolumn{2}{|c|}{ Sludge to fermentation } & 322 & 262 & 322 & 136 & 4,96 & 0,62 & 4,96 & 0,32 & 21 & 17 & 21 & 11 \\
\hline \multicolumn{2}{|c|}{ total sludge to fermentatior } & 540 & 565 & 540 & 442 & 7,86 & 11,00 & 7,86 & 10,72 & 67 & 82 & 67 & 71 \\
\hline \multicolumn{2}{|c|}{$\%$ conversion to biogas } & 0,50 & 0,50 & 0,50 & 0,50 & & & & & & & & \\
\hline \multicolumn{2}{|c|}{$\% \mathrm{CH} 4$ of biogas } & 0,65 & 0,65 & 0,65 & 0,65 & & & & & & & & \\
\hline \multicolumn{2}{|l|}{$\%$ org in liquid } & 0,10 & 0,10 & 0,10 & 0,10 & 0,91 & 0,91 & 0,91 & 0,91 & 0,9 & 0,9 & 0,9 & 0,9 \\
\hline \multicolumn{2}{|l|}{$\mathrm{CH} 4$ produced } & 175 & 184 & 175 & 144 & & & & & & & & \\
\hline \multicolumn{2}{|l|}{$\mathrm{CO} 2$ produced } & 94 & 99 & 94 & 77 & & & & & & & & \\
\hline \multicolumn{2}{|c|}{ Residue to farmland } & 310 & 325 & 310 & 254 & 0,72 & 1,01 & 0,72 & $0,98^{\prime}$ & $6,66^{\prime}$ & $8,17^{\prime}$ & $6,66^{\prime}$ & 7,13 \\
\hline Reject water & & 54 & 56 & 54 & 44 & $7,14^{\prime}$ & 9,99 & 7,14 & 9,74 & 60 & 74 & 60 & 64 \\
\hline Polish sep effic $n$ & Poush $=$ & 0,55 & 0,25 & 0,55 & 0,55 & 0,8 & 0,1 & 0,8 & 0,8 & 0,55 & 0,55 & 0,55 & 0,55 \\
\hline left to effluent & & 46 & 62 & 46 & 19 & 0,15 & 0,08 & 0,15 & 0,01 & 13,4 & 10,9 & 13,4 & 7,1 \\
\hline sludge to ferme & ntation & 56 & 21 & 56 & 24 & 0,60 & 0,01 & 0,60 & 0,04 & 16,3 & 13,3 & 16,3 & 8,7 \\
\hline
\end{tabular}

For electricity, the dfference is relatively small although higher for cases 1 and 3, while methane production is lowest in case 4 , where a lot of the organics is sent to farmland directly, as seen as $\mathrm{TOC} / \mathrm{h}$ to farmland. Concerning $\mathrm{P}$ to farmland as well as $\mathrm{N}-\mathrm{NH}_{4}$ case 1 has the lowest distribution while in case 4 , the highest on especially $\mathrm{NH}_{4}$.

All four cases can be implemented in the same WWTP with only small modifications, and in reality it is possible to switch between the different operational modes. It is mostly the addition of the nano membrane filter that differ this plant from "normal ones". This can be useful when it comes to optimization related to the use of water for irrigation and addition of "natural" fertilizers as especially dissolved $\mathrm{NH}_{4}$ and $\mathrm{PO}_{4}$. Cases 1 , 2 and 3 can absolutely be implemented while case 4 may be sensitive from a hygienic perspective. This water should not be distributed in crops close to harvest, to avoid risks for spreading infectious diseases. It is not only possible to switch between the different alternatives, but also variants in between can be used.

The optimization should be made to fulfill the crop demand as far as possible. In Figure 3, an example of demand and supply of water respectively supply of water and nutrients can be seen. The water can be cleaned effluent to meet the water demand, while the nutrient supply is covered by operating the plant as suitable with the different operational modes in the four cases. You first cover the nutrient demand, and then fill up with cleaned water to fulfil the water demand. When the crops are very small irrigation is important. Later on nutrient will be more important to stimulate the growth rate. By switching between the different alternatives water with different amount of nutrients can be taken out, depending on these different demands over the growth season. If the $\mathrm{NH}_{4}$ and $\mathrm{PO}_{4}$ should be used far away from the WWTP, it might be interesting to precipitate these with $\mathrm{MgO}$ or $\mathrm{CaO}$. The product then could be transported and stored in a relatively compact way Levlin and Hultman (2003) indicate an efficiency of at least $60 \%$ for Magnesiumammoniumphosphate can be achieved fromreject water. The electricity demand and the production of biogas are two other variables to include in an optimization to govern what alternative to use at different times depending on the value of electricity respectively methane during different situations.

The control can be based on mass balance simulation of the process that can be made on-line continuously. By combining this with prediction of demands from the farmland production and distribution, plans can be made for how to optimize both plant operation and irrigation. By combining with cost calculations for chemicals, 
electricity and value of biogas and nutrients produced economic optimization could also be made.

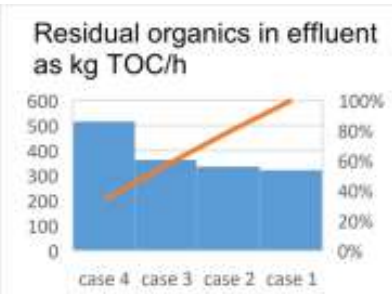

Total Nitrogen as kg NH4/h in effluent

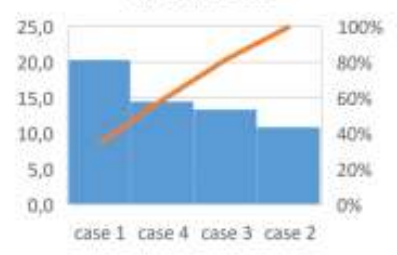

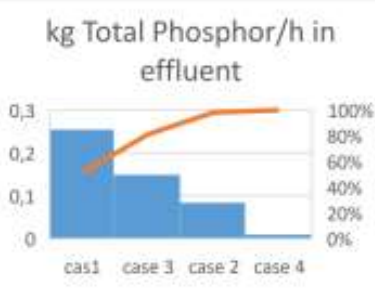

kW electricity for airation and pumping inside plant

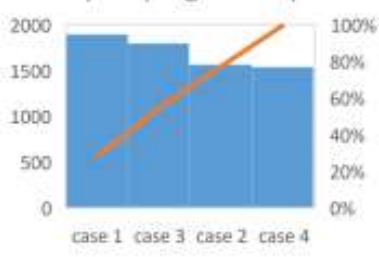

Methane produced as $\mathrm{kg}$ $\mathrm{CH} 4 / \mathrm{h}$

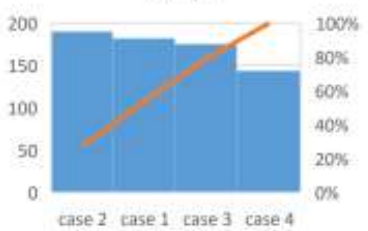

Total Phosphor to farmland as $\mathrm{kg} \mathrm{TP} / \mathrm{h}$

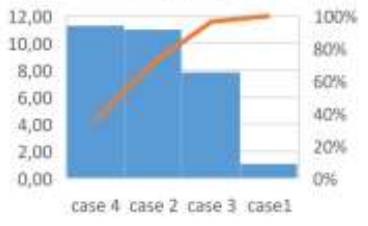

Organic residues to farmland in $\mathrm{kg} \mathrm{TOC} / \mathrm{h}$

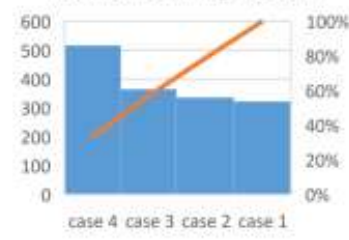

Total nitrous compounds as $\mathrm{kg} \mathrm{NH} 4 / \mathrm{h}$ to farmland

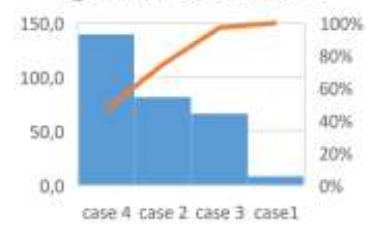

Figure 2. Comparison between the four cases with respect to effluent levels respectively distribution to farmland of TOC, $\mathrm{PO}_{4}$ and $\mathrm{NH}_{4}$ as $\mathrm{kg} / \mathrm{h}$. Also $\mathrm{kW}$ electricity demanded and biogas produced as $\mathrm{kg} \mathrm{CH}_{4} / \mathrm{h}$.

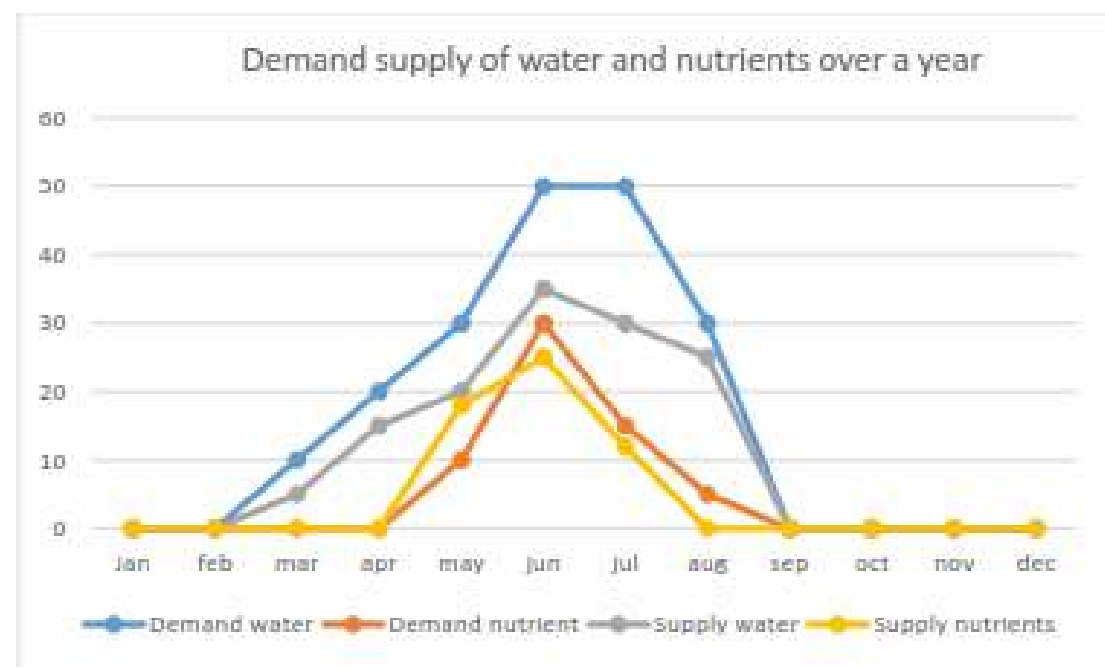

Figure 1. Three different causal loops identified by the conceptualized simulation model.

\section{Conclusions}

In this paper it was discussed how the WWTP can be controlled for irregation with respect to different ways of operations by simulating different ways of operations. These varying operations mode can be determined from the demand for water respectively nutrients like $\mathrm{NH}_{4}$ and $\mathrm{PO}_{4}$ over the growth season. The simulation can be made on-line for continuously follow the balances. By combining this with prediction of demands from the farmland production and distribution, plans can be made for how to optimize both plant operation and irrigation. By combining with cost calculations for chemicals, electricity and value of biogas and nutrients produced economic optimization can also be made.

\section{References}

A. Anbalagan, S. Schwede, C. F. Lindberg, and E. Nehrenheim. Continuous microalgae-activated sludge flocs for remediation of municipal wastewater under low temperature. In 1st IWA Conference on Algal.

Tchnologies for Wastewater Treatment and Resource Recovery, UNESCO-IHE, Delft, Netherlands, 2017. 
D. Dubber and N. F. Gray. Replacement of chemical oxygen demand (COD) with total organic carbon (TOC) for monitoring wastewater treatment performance to minimize disposal of toxic analytical waste. J Environ Sci Health A Tox Hazard Subst Environ Eng., 45(12):1595-600, 2010. doi: 10.1080/10934529.2010.506116.

Enerwater. Standard method and online tool for assessing and improving the energy efficiency of waste water treatment plants, H2020-EE-2014-3-MarketUptake, 2015.

Linda Kanders. Start-up and operational strategies for deammonification plants. $\mathrm{PhD}$ thesis, Malardalen University Press, June 2019.

E. Levlin and B. Hultman. Phosphorus recovery from phosphate rich sidestreams in wastewater treatment plants, 2003.

https://www.kth.se/polopoly_fs/1.650637.1550156562!/JP S10s47.pdf

K. Mizuta and M. Shimada. Benchmarking energy consumption in municipal wastewater treatment plants in Japan. Water Sci Technol., 62(10):2256-2262, 2010. doi: 10.2166/wst.2010.510.

G. K. Morse, S. W. Brett, J. A. Guy, and J. N. Lester. Review: Phosphorous removal and recovery technologies. The science of total environment, 212: 69-81, 1998.

Renan Barroso Soares, Marina Santos Memelli, Regiane Pereira Roque, Ricardo Franci Gonçalves. Comparative Analysis of the Energy Consumption of Different Wastewater Treatment Plants. International Journal of Architecture, Arts and Applications, 3(6): 79-86, 2017.

Hillar Toomiste, Jüri Haller, Mait Kriipsalu, and Valdo Kuusemets. Phosphorus balance at Tartu wwtp,estonia. Conference proceedings Linnaeus ECO-TECH'10 Kalmar, Sweden, November 22-24, 2010.

J. Desloover, S. E. Vlaeminck, P. Clauwaert, W. Verstraete, and $\mathrm{N}$. Boon. Strategies to mitigate $\mathrm{N}_{2} \mathrm{O}$ emissions from biological nitrogen removal systems. Curr. Opin. Biotecnology 23: 474-482, 2012. doi: 10.1016/j.copbio.2011.12.030.

Constantinos C. Pantelides. The Consistent Initialization of Differential-Algebraic Systems. SIAM Journal on Scientific and Statistical Computing, 9(2): 213-231, 1988. 